\title{
Tissue loss induces switching of feeding mode in spionid polychaetes
}

\author{
Sara M. Lindsay*, Sarah A. Woodin \\ Department of Biological Sciences, University of South Carolina, Columbia, South Carolina 29208, USA
}

\begin{abstract}
For many animals, foraging is a complex activity involving decisions of when, where, and how to feed, as well as what to feed upon. Flexibility in foraging (i.e. switches among activities, habitats, or food items) is presumed to contribute to overall fitness, and is an important component of theoretical models of animal feeding behavior. The importance of switching among feeding methods is less well described, but may be very important for marine sediment dwellers (infauna). For example, many infauna switch between suspension and surface-deposit feeding depending on water flow. However, infauna often lose feeding appendages to browsing predators, and the ability to switch to alternative feeding methods which are not dependent on those appendages should be advantageous after such tissue losses. Laboratory experiments examined the effect of feeding appendage loss on 2 species of spionid polychaetes which have different alternative feeding modes when intact. Behavior of individual worms with 0,1 or 2 palps removed was videotaped for $2 \mathrm{~h}$ within 3 to $4 \mathrm{~d}$ of palp removal. Loss of both feeding palps induced switches to alternative feeding modes involving mouth-feeding: Rhynchospio glutaeus fed on the surface, Pseudopolydora kempi japonica fed below the surface. As measured by time spent feeding and by fecal production, the alternative was effective for $R$. glutaeus but not for $P . k$. japonica. The results emphasize the potential importance of injury and subsequent switching as factors determining feeding behavior.
\end{abstract}

KEY WORDS: Browsing · Foraging behavior - Infauna P Polychaete - Predation risk - Spionid · Surfacedeposit feeding $\cdot$ Sublethal predation

\section{INTRODUCTION}

As animals forage, they make decisions of when, where, and how to feed, as well as what to feed upon. To best take advantage of the changing environments they inhabit, animals often switch between activities, foraging sites, and food items. In fact, this flexibility is a central component in attempts to describe animal foraging behavior theoretically.

Predator switching among prey items (optimal diet) or habitats (optimal patch use) is an important part of the optimal foraging literature, but there is little emphasis on changes in foraging behavior or mode of food collection (e.g. Holling 1959, MacArthur \& Pianka 1966, Charnov 1976a, b, Sih 1982, Stephens \& Krebs 1986; reviews by Schoener 1971, Krebs 1978, Hughes 1980). Another body of literature emphasizes actual changes in foraging behavior. For example, lions sea-

•E-mail: lindsay@biol.sc.edu sonally switch from social hunting in large prides to solitary and pair hunting (Caraco \& Wolf 1975). Among non-social animals, the gecko Ptenopus garrulus switches from its normal sit-and-wait predatory behavior to wide-ranging foraging tactics during swarms of termites (Huey \& Pianka 1981). Some marine calanoid copepods employ 2 distinct modes of feeding: oriented pounce and capture of larger prey, or low amplitude flapping of specific appendages to funnel smaller particles to the mouth (Price \& Paffenhöfer 1986, Price 1988). Regardless of emphasis, such switches among prey types, foraging habitats, or foraging behaviors/ modes are typically discussed as ways to increase net caloric gain or to minimize predation risk.

Changes in feeding behavior also occur when an organism's normal feeding mode is unavailable. Factors affecting the availability of behaviors include morphological constraints, relative predation risk, competition, environmental conditions and mechanical damage or injury to the animal. Predation risk is known to influ- 
ence animal decisions of when, where, and how to forage (reviewed by Dill 1987, Sih 1987, Lima \& Dill 1990). Shifts in habitat use due to competition may also necessitate shifts in food-searching behavior (MacArthur \& Pianka 1966). In addition, environmental factors can prompt switches to alternative feeding behaviors. For example, the desert lizard Aporosaura anchietae waits for insects and seeds floating on the wind, but forages widely for ants when the air is still (abstract, M. D. Robinson 1978, as cited in Huey \& Pianka 1981). Similarly, in marine habitats, changes in flow regime can influence feeding mode. Increased water flow or changes in flow direction induce switches from surface-deposit feeding to suspension feeding in some marine polychaete worms (Taghon et al. 1980, Turner \& Miller 1990, Miller et al. 1992) and cause reduced feeding in some polychaetes (Dauer 1983, Taghon \& Greene 1992) and marine clams (Levinton 1991). For marine sediment dwellers (infauna) such as polychaete worms, normal feeding behaviors may also be precluded by tissue loss to browsing predators. Just as lethal predation risk can influence foraging behavior, tissue loss to browsing predators (i.e. sublethal predation) should also influence marine infaunal feeding behavior. The ability of these animals to switch to an alternative feeding mode may be very important.

Damage due to sublethal predation is common in marine environments. Infauna frequently lose body parts that are exposed above the sediment surface (brittlestar arms: Bowmer \& Keegan 1983, Stancyk et al. 1994; tentacles and tails of worms: de Vas 1979a, b, Clavier 1984; siphons of clams: Edwards \& Steele 1968, Peterson \& Quammen 1982, de Vlas 1985). Such tissue losses affect growth (de Vlas 1979b, Peterson \& Quammen 1982, Coen \& Heck 1991, Kamermans \& Huitema 1994), reproduction (Zajac 1985), activity and exposure patterns (Woodin 1984, Clements 1985, Lindsay \& Woodin 1992, Kamermans \& Huitema 1994). Among infaunal taxa, feeding behaviors vary widely and typically include subsurface-deposit feeding, surfacedeposit feeding and suspension feeding. Surfacedeposit feeding and suspension feeding usually involve tissue exposure above the sediment refuge (sensu Blundon \& Kennedy 1982) as animals collect food from the sediment surface or the overlying water. Subsurface-deposit feeding, where animals collect food below the sediment surface, typically does not involve tissue exposure outside the sediment refuge, except, perhaps, during defecation. Individual infauna often have several different feeding modes. For example, a single spionid polychaete may feed by surfacedeposit feeding using appendages, surface-deposit feeding using the eversible pharynx ('mouth') directly, or suspension feeding using appendages (Daro \& Polk 1973, Dauer et al. 1981, Lindsay \& Woodin 1992).
Depending on the type of tissue lost, sublethal predation may remove a potential feeding behavior. When feeding appendages are lost (i.e. bivalve siphons, brittlestar arms, polychaete tentacles and palps), infauna may realize a profound advantage in continued feeding and faster regeneration if they can switch to alternative feeding behaviors. We removed feeding appendages of 2 polychaete species with different alternative feeding modes to examine the effect of this type of tissue loss on feeding behavior.

Rhynchospio glutaeus (Ehlers) (synonymous to Malacocerus glutaeus) and Pseudopolydora kempi japonica Imajima \& Hartman are intertidal spionid polychaetes which commonly lose feeding appendages. At False Bay, Washington, USA, R. glutaeus occurs in the lower intertidal, $P . k$. japonica in the upper intertidal, and approximately 15 to $20 \%$ of collected individuals of both species are missing 1 or both feeding palps (Lindsay \& Woodin 1992). Both species are surfacedeposit feeders, using thin, translucent palps to collect sediment and detritus particles (Woodin 1982, Miller \& Jumars 1986). Each species has an alternative feeding mode when intact. Intact $P . k$. japonica coil their palps up into the water column, collecting particles in suspension, when flow rates increase (Taghon et al. 1980). Suspension feeding by $R$. glutaeus in flow has not been reported. Observations of a closely related species, Malacocerus indicus, indicate individuals do not suspension feed in currents that would induce such behavior in other spionids (Dauer \& Ewing 1991). Dauer \& Ewing (1991) suggest that the simple palp morphology of $M$. indicus, with only a single functional group of frontal cilia lining the food groove of the palp, may prevent this species from effective suspension feeding. Our initial observations of $R$ glutaeus palps using a scanning electron microscope revealed a field of cilia lining the food groove. Cilia were sparser at the base of the palps, and we saw no evidence of spatial organization of cilia into bundles at the latero-frontal edge of the groove or lateral to the groove. Thus, ciliation patterns associated with palps of spionids that switch between deposit and suspension feeding (e.g. Paraprionospio pinnata and Streblospio benedicti; Dauer 1984,1985 ) appear to be lacking in $R$. glutaeus. These preliminary observations suggest that suspension feeding may not be an available alternative for $R$. glutaeus. Instead, intact $R$. glutaeus extend body segments to ingest surface sediment with the everted pharynx (hereafter referred to as 'mouth feeding') (Woodin 1982). Thus, the normal alternative feeding mode of $R$. glutaeus is available following complete palp loss, while that of $P$. $k$. japonica is not. However, no obvious morphological constraint prevents $P . k$. japonica from feeding with its mouth. Given these different alternative feeding modes, the commonness of 
palp loss in both species, and the different consequences of palp loss, we asked the following questions: first, following palp loss, do worms shift the time allocated to various behaviors? Second, do worms missing palps switch to mouth feeding? And third, if they do, can this switch compensate for the energetic cost associated with palp loss, as estimated by reduced time spent feeding?

\section{MATERIALS AND METHODS}

Adult worms were collected from False Bay, Washington, USA $\left(48^{\circ} 29^{\prime} \mathrm{N}, 123^{\circ} 04^{\prime} \mathrm{W}\right)$ and transferred to the Friday Harbor Laboratories (University of Washington) for observation. Worms were randomly assigned to 3 treatments: Intact (control), One palp, and No palps (both palps removed). Palps were removed with fine forceps and worms were allowed a minimum of $24 \mathrm{~h}$ to recover from handling before videotaping of their feeding behavior; see Lindsay \& Woodin (1992) for details. Because suspension feeding is impossible after complete palp loss, this study was restricted to observations of surface-deposit feeding, and worms were placed in still seawater for observation. Under these conditions, both species are surfacedeposit feeders. These conditions do occur in nature. For example, individuals of both species may be observed surface-deposit feeding in the still water of tide pools at low tide (Lindsay pers. obs.), and while sediment transport due to wave action is common in False Bay, periods of low or no transport are also common (Miller \& Sternberg 1988).

Individual worms in cores of sediment (False Bay surface sediment, median grain size $0.18 \mathrm{~mm}$, silt-clay $10 \%$ ) were submerged in still seawater $\left(13\right.$ to $\left.14^{\circ} \mathrm{C}\right)$ and videotaped for $2 \mathrm{~h}$ using a video camera mounted on a dissecting microscope with illumination from redfiltered fiber optic lights. Due to the high resolution of S-VHS videotaping, both the palps and segments were clearly visible against the sediment surface in these low light conditions. After preliminary observations, the time period of $2 \mathrm{~h}$ was chosen as being long enough to accurately sample the full suite of behaviors worms displayed, but still short enough so that depression of feeding rate due to accumulation of fecal pellets was unlikely (Miller \& Jumars 1986, Taghon \& Greene 1992). To limit the range of regenerative states, worms were placed into their individual containers in groups of 9 ( 3 worms per treatment). All 9 worms were filmed, and then another group of 9 was prepared. Typically, worms within a group were filmed within 3 to $4 \mathrm{~d}$ of palp removal (in most cases, 1 worm per treatment per night; i.e. a total of 3 worms per night). The order in which worms from each treatment were videotaped each night was random. Worms were videotaped only if feces (i.e. evidence of feeding) were seen on the sediment surface. Thus, all worms had returned to some level of activity before observation. Existing feces were removed from the cores before videotaping. A total of 37 Rhynchospio glutaeus were observed: Intact (control), $\mathrm{n}=12$; One palp, $\mathrm{n}=12$; No palps, $\mathrm{n}=13$. A total of 35 Pseudopolydora kempi japonica were observed: Intact, $\mathrm{n}=11$; One palp, $\mathrm{n}=12$; No palps, $\mathrm{n}=12$.

After videotaping, palp lengths were measured for each worm in order to make crude estimates of regeneration rate. For example, more than $70 \%$ of the worms losing palps were videotaped within $3 \mathrm{~d}$ following palp removal, at which point Rhynchospio glutaeus which lost both palps had regenerated palps which were 0.1 $\pm 0.2 \mathrm{~mm}$ long (mean $\pm \mathrm{SD}$ ) compared to palps of intact worms which were $2.7 \pm 1.1 \mathrm{~mm}$ long. At $3 \mathrm{~d}$ following palp removal, Pseudopolydora kempi japonica losing both palps had regenerated palps which were $1.1 \pm 0.1$ $\mathrm{mm}$ long compared to palps of intact worms which were $10.2 \pm 2.11 \mathrm{~mm}$ long. In fact, one rationale for the lack of flow in our experiments was to maximize the opportunity for a worm with $\leq 1 \mathrm{~mm}$ long palps to feed; we assume that effective suspension feeding with a palp of this length is much less likely than surfacedeposit feeding, since suspension feeding spionids often rely on coiling their palps into water currents to trap particles (Taghon et al. 1980, Dauer 1983, Miller et al. 1992).

The 2 h video records were scored for behavior type and duration, producing time budgets for each worm. Activities outside the tube were assigned to one of the 5 behaviors defined in Table 1. Activities inside the tube (e.g. moving up and down, ventilation) were difficult to score reliably, so they were combined into 1 category, time visible inside the tube, and analysed separately. Individual time budgets were averaged for each treatment and means compared using ANOVA. When

Table 1. Definitions of spionid polychaete behaviors analyzed in this study

\begin{tabular}{|ll|}
\hline Behavior & Operating definition \\
\hline Feeding & $\begin{array}{l}\text { Collection or ingestion of sediment } \\
\text { by palp(s) or mouth }\end{array}$ \\
& $\begin{array}{l}\text { Palp(s) sweeping surface in arcs; } \\
\text { body moving on the surface; either } \\
\text { or both }\end{array}$ \\
Tube maintenance & $\begin{array}{l}\text { Tube building and tube cleaning } \\
\text { Defecation }\end{array}$ \\
Other & $\begin{array}{l}\text { Expulsion of fecal rods from the } \\
\text { tube by palp(s) or body }\end{array}$ \\
& $\begin{array}{l}\text { Palp(s) and/or body lying still or } \\
\text { twitching on the surface or in the } \\
\text { water column }\end{array}$ \\
\hline
\end{tabular}


necessary, data were transformed to meet assumptions of ANOVA. Homogeneity of variances was tested using the Scheffé-Box test (Sokal \& Rohlf 1981). All data analysis was performed with PC-SAS, version 6.04 (SAS Institute, Inc., Cary, NC, USA). Because the times spent in separate behaviors are not necessarily independent, ANOVA p-values were compared to a corrected alpha level of 0.0033 (Bonferroni correction: 0.05 divided by 15 ANOVAs per species) to determine significance.

\section{RESULTS}

\section{Effect of palp loss on activity}

Table 2 lists the effect of palp loss on the average time worms spent in each behavior during the $2 \mathrm{~h}$. Total activity outside the tube decreased significantly with complete palp loss in both species. Intact and 1 palp Rhynchospio glutaeus were about $4 \times$ more active than $R$. glutaeus with no palps. Intact and 1-palp

Table 2. (A) Rhynchospio glutaeus and (B) Pseudopolydora kempi japonica. Effect of palp Ioss on worm activity: time (s) spent in each activity, means $(95 \% \mathrm{CI})$ are back-transformed from $\log (x+1)$ values used in 1 -way ANOVAs with palp removal treatment as the main factor - Palp removal had a significant effect on the variable. To determine ANOVA significance, $p$-values were compared to a Bonferroni corrected $\alpha=0.0033$. For variables showing a significant effect of palp removal treatment, Tukey's studentized range test was used to compare treatment means $(\alpha=0.05)$; means underlined by the same line are not significantly different. 2: Intact (control); 1: 1 palp; 0: No palps. One-way ANOVA degrees of freedom (df) were (A) 2,33 and (B) 2,31

\begin{tabular}{|c|c|c|c|c|c|}
\hline Activity & Intact & 1 palp & No palps & $\mathrm{p}>F$ & Tukey \\
\hline \multicolumn{6}{|l|}{ A. Rhynchospio glutaeus } \\
\hline Total activity outside tube & $\begin{array}{l}1748.8 \\
(1220.8,2505.10)\end{array}$ & $\begin{array}{l}1948.8 \\
(1108.2,3426.7)\end{array}$ & $\begin{array}{l}451.9 \\
(199.9,1019.9)\end{array}$ & $0.0013^{\circ}$ & $\underline{12} \underline{0}$ \\
\hline Feeding & $\begin{array}{l}811.8 \\
(501.3,1314.2)\end{array}$ & $\begin{array}{l}958.4 \\
(557.5,1647.2)\end{array}$ & $\begin{array}{l}115.4 \\
(41.1,321.1)\end{array}$ & $0.0001^{\circ}$ & $\underline{12} \underline{0}$ \\
\hline Searching & $\begin{array}{l}444.5 \\
(233.2,842.9)\end{array}$ & $\begin{array}{l}393.5 \\
(93.8,1640.7)\end{array}$ & $\begin{array}{l}159.6 \\
(46.3,544.4)\end{array}$ & $0.3402 \mathrm{~ns}$ & \\
\hline Tube maintenance & $\begin{array}{l}2.0 \\
(0.3,5.7)\end{array}$ & $\begin{array}{l}4.6 \\
(1.3,12.4)\end{array}$ & $\begin{array}{l}1.3 \\
(0.1,4.1)\end{array}$ & $0.2399 \mathrm{~ns}$ & \\
\hline Defecation & $\begin{array}{l}4.1 \\
(1.3,10.3)\end{array}$ & $\begin{array}{l}5.3 \\
(2.0,12.4)\end{array}$ & $\begin{array}{l}2.6 \\
(0.6,6.8)\end{array}$ & $0.5086 \mathrm{~ns}$ & \\
\hline Other & $\begin{array}{l}320.2 \\
(140.6,727.6)\end{array}$ & $\begin{array}{l}293.8 \\
(155.4,554.6)\end{array}$ & $\begin{array}{l}11.5 \\
(1.1,74.8)\end{array}$ & $0.0003^{\circ}$ & $\underline{21} \underline{0}$ \\
\hline Visible in tube & $\begin{array}{l}2.4 \\
(-0.5,23.5)\end{array}$ & $\begin{array}{l}1.4 \\
(-0.3,7.6)\end{array}$ & $\begin{array}{l}99.9 \\
(43.5,227.6)\end{array}$ & $0.0001^{\circ}$ & $\underline{0} 21$ \\
\hline Invisible ${ }^{a}$ & $\begin{array}{l}4785.9 \\
(3498.3,6073.5)\end{array}$ & $\begin{array}{l}4583 \\
(3523.5,5642.5)\end{array}$ & $\begin{array}{l}6154.7 \\
(5583.9,6725.4)\end{array}$ & $0.0257 \mathrm{~ns}$ & \\
\hline \multicolumn{6}{|c|}{ B. Pseudopolydora kempi japonica } \\
\hline Total activity outside tube & $\begin{array}{l}5699.3 \\
(4318.2,7522.2)\end{array}$ & $\begin{array}{l}6436.2 \\
(5995.5,6909.3)\end{array}$ & $\begin{array}{l}54.3 \\
(16.2,176.5)\end{array}$ & $0.0001^{\circ}$ & $\underline{12} \underline{0}$ \\
\hline Feeding & $\begin{array}{l}4356.1 \\
(3012,6299.9)\end{array}$ & $\begin{array}{l}3781.7 \\
(2574.1,5555.5)\end{array}$ & $\begin{array}{l}3.8 \\
(0.4,14.9)\end{array}$ & $0.0001^{\circ}$ & $\underline{21} \underline{0}$ \\
\hline Searching & $\begin{array}{l}335.8 \\
(137,821.1)\end{array}$ & $\begin{array}{l}423.4 \\
(109.8,1624.9)\end{array}$ & $\begin{array}{l}34.8 \\
(11.4,101.7)\end{array}$ & $0.0024^{\bullet}$ & $\underline{12} \underline{0}$ \\
\hline Tube maintenance & $\begin{array}{l}0.6 \\
(-0.4,3.3)\end{array}$ & $\begin{array}{l}0.2 \\
(-0.1,0.6)\end{array}$ & $\begin{array}{l}2.0 \\
(0.01,8.2)\end{array}$ & $0.2430 \mathrm{~ns}$ & \\
\hline Defecation & $\begin{array}{l}26.3 \\
(16.2,42.2)\end{array}$ & $\begin{array}{l}25.7 \\
(10.9,58.7)\end{array}$ & $\begin{array}{l}0.6 \\
(-0.1,1.9)\end{array}$ & $0.0001^{\circ}$ & $\underline{21} \underline{0}$ \\
\hline Other & $\begin{array}{l}374.8 \\
(211.5,663.5)\end{array}$ & $\begin{array}{l}865.5 \\
(519.7,1441.1)\end{array}$ & $\begin{array}{l}1.9 \\
(-0.3,10.8)\end{array}$ & $0.0001^{\circ}$ & $12 \underline{0}$ \\
\hline Visible in tube & $\begin{array}{l}0 \\
(0,0)\end{array}$ & $\begin{array}{l}0.7 \\
(-0.1,2.2)\end{array}$ & $\begin{array}{l}234.3 \\
(169.6,322.6)\end{array}$ & $0.0001^{\circ}$ & $\underline{0} \underline{12}$ \\
\hline Invisible & $\begin{array}{l}787.3 \\
(435.5,1411.5)\end{array}$ & $\begin{array}{l}515.1 \\
(294.1,890.2)\end{array}$ & $\begin{array}{l}6781.7 \\
(6605.9,6917.3)\end{array}$ & $0.0001^{\circ}$ & $02 \underline{1}$ \\
\hline
\end{tabular}


Pseudopolydora kempi japonica were approximately $100 \times$ more active than $P . k$. japonica with no palps.

In both species, intact and 1-palp worms spent the same amount of time feeding (i.e. ingesting particles) (Table 2). Intact Rhynchospio glutaeus spent $7 \times$ more time feeding in $2 \mathrm{~h}$ compared to worms with no palps (Table 2A), and intact Pseudopolydora kempi japonica spent $1150 \times$ more time feeding in $2 \mathrm{~h}$ compared to worms with no palps (Table 2B). Searching behavior is another aspect of foraging and in this study was defined as palps sweeping the surface in circles, the body moving across the surface, or both. Palp loss had no significant effect on the time $R$. glutaeus spent searching (Table 2A). In contrast, intact and 1-palp $P$. $k$. japonica spent $10 \times$ more time searching relative to worms with no palps (Table $2 \mathrm{~B}$ ).
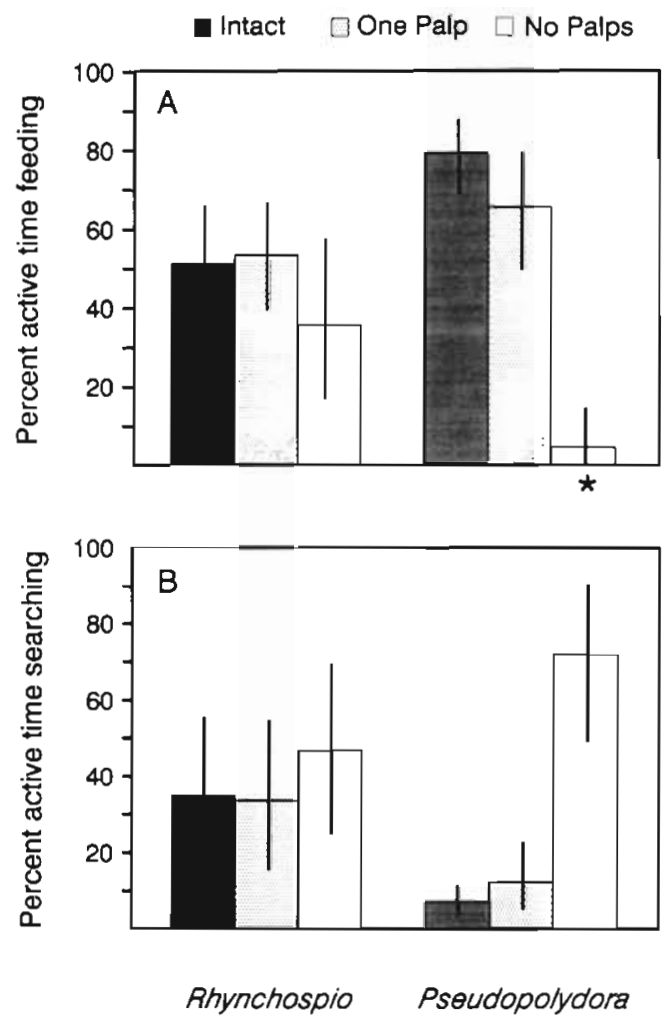

Fig. 1. Rhynchospio glutaeus and Pseudopolydora kempi japonica. Percent of total exposed time spent (A) feeding and (B) searching by worms. Means (bars) and $95 \%$ CI (lines) are back-transformed from arcsin[square root $(x)$ ] values used in ANOVA. (*) Mean is significantly different from the other treatments within that behavior and species $(\alpha=0.05$, Tukey's studentized range test). ANOVA results were as follows ( $p \leq 0.0033$ indicates a significant effect of palp removal): R. glutaeus feeding, $\mathrm{MS}=0.12, F=1.51, \mathrm{df}=2,33, \mathrm{p}=0.2351$; $P$. $k$. japonica feeding, $\mathrm{MS}=2.46, F=44.82, \mathrm{df}=2,31, \mathrm{p}=$ $0.0001 ; R$. glutaeus searching, $\mathrm{MS}=0.07, F=0.58, \mathrm{df}=2,33$, $\mathrm{p}=0.5675 ; P . k$. japonica searching, $\mathrm{MS}=1.82, F=30.41$, $\mathrm{df}=2,31, \mathrm{p}=0.0129$
Both species spent very little time on tube maintenance or defecation. Palp loss did not affect the time Rhynchospio glutaeus spent in either of these activities (Table 2A). Nor did palp loss affect the time Pseudopolydora kempi japonica spent on tube maintenance (Table 2B). But P. $k$. japonica with no palps spent significantly less time defecating compared to worms with 1 or both palps (Table 2B). The behavioral category 'other' is a catch-all including activity by worm palps or bodies on the surface in which there was no obvious movement or 'purpose'. In both species, worms with no palps spent significantly less time engaged in other activities compared to controls (Table 2).

For both species, worms with 1 or both palps were visible inside their tubes for very little time (Table 2) the worms were either outside the tube and active or completely submerged (invisible in tube). Worms with no palps were visible in their tubes for significantly more time than worms with 1 or both palps (Table 2). The precise nature and timing of the behaviors inside the tube remains unresolved, but worms were typically ventilating their tubes by undulating their bodies, moving up and down inside the tube, or simply stationary inside the tube. While worms were visible inside the tube, we did not observe any feeding on sediments below the surface. Rhynchospio glutaeus with no palps tended to be invisible (i.e. completely submerged) for more time than worms with 1 or both palps, but the differences were not significant (Table 2). Pseudopolydora kempi japonica with no palps were invisible for significantly more time than worms with either 1 or both palps.

\section{Allocation of exposed time}

Worms showed a number of behaviors while partially outside their tubes. Because reduced total activity levels may obscure shifts in worms' allocation of exposed time to different behaviors, we also examined the effect of palp loss on worms' behavior as the percentage of total time active outside the tube. As shown in Fig. 1A, Rhynchospio glutaeus allocated the same proportion of exposed time to feeding regardless of palp loss. Thus, the reduction in absolute feeding time (Table 2A) by worms with no palps apparently was a function of reduced activity, not of changes in time allocated to feeding. In contrast, intact Pseudopolydora kempi japonica allocated about $17 \times$ more exposed time to feeding compared to worms with no palps (Fig. 1A). There was no difference among treatments in the proportion of exposed time $R$. glutaeus spent searching (Fig. 1B). Unexpectedly, P. k. japonica without palps increased allocation of time to searching (about 10x) compared to intact worms (Fig. 1B), 
though the increase is not statistically significant using the conservative, corrected $\alpha=0.0033$ to determine ANOVA significance.

Both species spent only a very small percentage of exposed time on either tube maintenance or defecation. Among Rhynchospio glutaeus, palp loss had no effect on allocation of time to these behaviors [tube maintenance means: $0.2 \%$ (Intact), $0.3 \%$ (1 palp), $0.1 \%$ (No palps), ANOVA MS $=0.001, F=3.12, \mathrm{df}=$ $2,33, p=0.0575$; defecation means: $0.3 \%$ (Intact), $0.3 \%$ (1 palp), $0.4 \%$ (No palps), ANOVA MS $=0.001, F=$
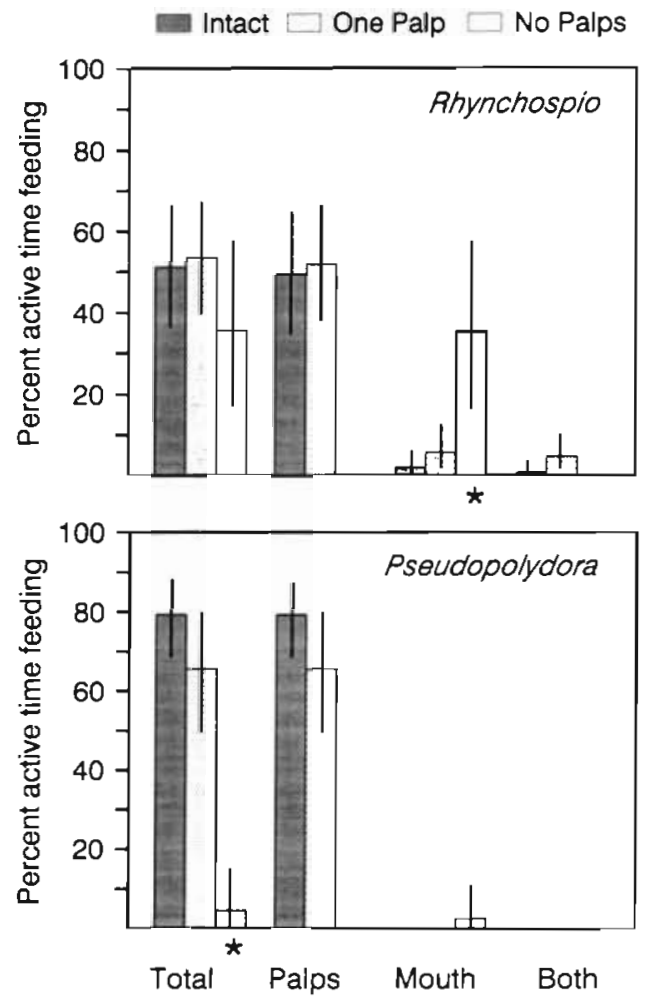

Fig. 2. Rhynchospio glutaeus and Pseudopolydora kempi japonica. Individual and concurrent contribution of palps and mouth to feeding as percentage of total exposed time. Means (bars) and 95\% CI (Innes) are back-transformed from $\arcsin [$ square root $(x)$ ] values used in ANOVA. (*) Mean is significantly different from the other treatments within that category ( $\alpha=0.05$, Tukey's studentized range test). Total: total percentage exposed time spent feeding. Palp: percentage of exposed time palp(s) were used to feed. Mouth: percentage of exposed time mouth was used to feed. Both: percentage of exposed time palp(s) and mouth were used concurrently to feed. Palp feeding and concurrent palp and mouth feeding were only possible for intact or 1-palp worms. Results of ANOVAs testing the effect of palp removal on feeding modes involving mouth feeding were as follows ( $p \leq 0.0033$ indicates a significant effect of palp removal): $R$. glutaeus mouth feeding, $\mathrm{MS}=0.83, F=12.63, \mathrm{df}=2,33, \mathrm{p}=0.0001 ; R$. glutaeus concurrent mouth and palp feeding, $M S=0.09, F=4.39, \mathrm{df}=$ $1,21, p=0.0485 ;$ P. k. japonica mouth feeding, $\mathrm{MS}=0.10, F=$ $4.90, \mathrm{df}=2,31, \mathrm{p}=0.0142 ; P . k$. japonica concurrent mouth and palp feeding did not occur
$0.23, \mathrm{df}=2,33, \mathrm{p}=0.7951 \mathrm{\}}$. While the percentage of exposed time Pseudopolydora kempi japonica spent defecating did not change with palp loss [means: $0.5 \%$ (Intact), $0.5 \%$ (1 palp), $0.2 \%$ (No palps), ANOVA MS = $0.004, F=1.21$, df $=2.31, p=0.3108]$, worms with no palps tended to allocate more $(30 \times)$ exposed time to tube maintenance [means: $0.02 \%$ (Intact), $0.001 \%$ (1 palp), $6.0 \%$ (No palps), ANOVA MS $=0.21, F=5.02, \mathrm{df}$ $=2,31, p=0.0129 \mathrm{~J}$. Interestingly, this increase, though not statistically significant, was due to increased tube building rather than tube cleaning.

For worms to surface-deposit feed after losing both palps, they must use their mouths (i.e. everted pharynx) to collect sediment from the surface. Fig. 2 illustrates the effect of palp loss on the contribution of palps and mouth to surface-deposit feeding by Rhynchospio glutaeus and Pseudopolydora kempi japonica. Note that worms with 1 or 2 palps may use palp(s) and mouth concurrently. In both species, worms with only 1 palp used that palp to feed for the same percentage of exposed time as intact worms used their 2 palps (Fig. 2). The percentage of exposed time spent mouth feeding was also similar in intact and 1-palp worms of both species. But mouth feeding increased significantly $(17 \times)$ in $R$. glutaeus without palps compared to intact worms (Fig. 2); a few individuals attempted to use their regenerating palps $(<0.5 \mathrm{~mm}$ long) to shovel particles towards the pharynx, but were not successful. $R$. glutaeus with 1 palp also increased concurrent palp and mouth feeding compared to controls (Fig. 2); regenerating palps were exposed with intact palps, but were not used. P. k. japonica without palps increased mouth feeding (Fig. 2), but this increase represents only $2.7 \%$ of exposed time allocated to feeding compared to $79 \%$ allocated to feeding by intact worms. Concurrent palp and mouth feeding did not occur in P. $k$. japonica with 1 or 2 palps (Fig. 2); worms were never observed attempting to use regenerating palp(s) to collect sediment.

\section{Fecal production}

Changes in fecal production can provide a valuable confirmation of any changes in feeding behavior. Fig. 3 shows the mean number of fecal rods produced by worms during the $2 \mathrm{~h}$ videotaping. Because worms were filmed only after they recovered from handling and had returned to feeding as evidenced by defecation, feces were expected for all individuals. Rhynchospio glutaeus produced similar numbers of feces regardless of palp loss (Fig. 3). Pseudopolydora kempi japonica with no palps produced significantly fewer fecal rods in $2 \mathrm{~h}$ compared to worms with 1 or both palps (Fig. 3). 


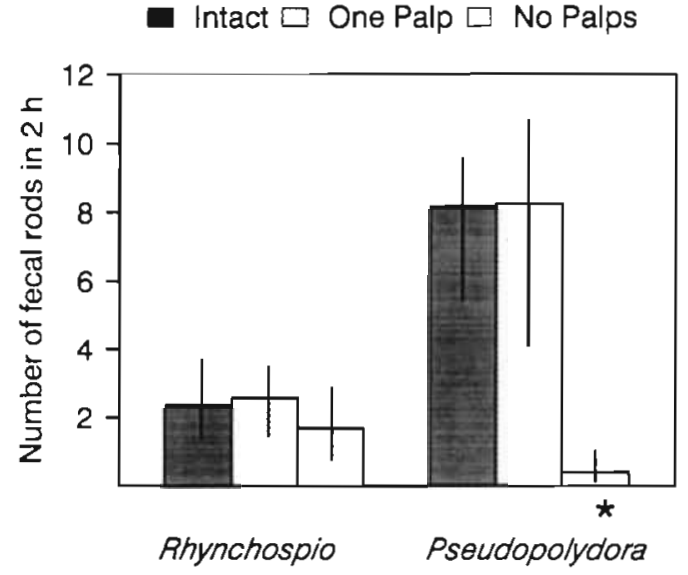

Fig. 3. Rhynchospio glutaeus and Pseudopolydora kempi japonica. Mean number of fecal rods produced by worms during the $2 \mathrm{~h}$ videotaping sessions (lines represent $95 \% \mathrm{CI}$ ). ( $\star$ Mean is significantly different from the other treatments within that species ( $\alpha=0.05$, Tukey's studentized range test). ANOVA results were as follows: $R$. glutaeus, $\mathrm{MS}=2.7, F=$ $0.65, \mathrm{df}=2,33, \mathrm{p}=0.5309 ; P . k$. japonica, $\mathrm{MS}=242.86, F=$ $20.3, \mathrm{df}=2,33, \mathrm{p}=0.0001$

\section{DISCUSSION}

Flexibility in foraging tactics can be important for animals in terms of fitness in variable environments. Animals can be flexible foragers by exploiting different habitats, different food types, or even different methods of collecting food. Marine sediment dwellers (infauna) often lose body tissue, including feeding appendages, to browsing predators such as fish and shrimp. Typically, infauna regenerate feeding appendages, but regeneration may be faster and consume less energetic reserves if the animals can continue to feed using an alternative feeding mode. We observed the effect of feeding appendage loss on feeding behavior of 2 species of spionid polychaetes. The results suggest a possible advantage for worms that switch feeding modes after palp loss.

Because exposure outside the sediment in marine habitats increases the risk of predation (Blundon \& Kennedy 1982) one might expect animals which feed on surface sediments, such as spionid polychaetes, to maximize time spent feeding when they are exposed. In the laboratory, intact spionids displayed a suite of identifiable behaviors during exposure on the sediment surface, of which feeding (i.e. collection and ingestion of sediment particles) was the most common (see Table 2; worms with intact palps). Possible responses to feeding palp loss that would maintain or increase feeding include no change in time exposed outside the tube with increased allocation of exposure time to feeding, and increased time exposed with the same allocation to feeding or with increased allocation to feeding. Alternatively, the physiological effect of palp loss, as well as the potential risk of additional tissue loss, might result in reduced time exposed outside the tube. In that case, increased allocation to feeding within the reduced exposure time might compensate for reduced activity. For the spionid polychaetes examined, continued feeding on the surface after complete palp loss was possible only if worms switched to an alternative feeding mode, mouth feeding.

Worms of both species spent significantly less time exposed outside the tube following removal of both palps (Table 2). Loss of 1 palp did not significantly affect the time worms of either species spent exposed outside the tube (Table 2), nor did it affect the time worms of either species allocated to feeding (Fig. 1). Pseudopolydora kempi japonica with no palps, however, significantly reduced the allocation of exposed time to feeding (Fig. 1A) while Rhynchospio glutaeus with no palps spent the same amount of exposed time feeding regardless of palp loss (Fig. 1A), suggesting that $R$. glutaeus without palps switched to mouth feeding. In fact, both species switched to mouth feeding on the surface after losing both palps (Fig. 2). R. glutaeus with 1 palp also increased concurrent mouth and palp feeding (Fig. 2). The time spent mouth feeding by P. $k$. japonica with no palps represents less than $5 \%$ of their exposed time and is trivial given the reduced total activity (Table 2). However, it is clear that $P$. $k$. japonica are not morphologically constrained from mouth feeding.

In terms of absolute time spent feeding, neither species fully compensated for complete palp loss, though mouth feeding by Rhynchospio glutaeus seems to have reduced the effect of palp loss. Had $R$. glutaeus without palps spent the same proportion of active time mouth feeding as did controls (about $2 \%$; Fig. 2), then absolute time feeding would have been drastically reduced: $2 \% \times$ average total activity of $451.9 \mathrm{~s}=9.04 \mathrm{~s}$ feeding, a $98.8 \%$ reduction compared to controls versus the $78.8 \%$ reduction actually observed. This suggests an energetic advantage to switching for $R$. glutaeus since the absolute time spent feeding will be directly related to energy gain (Schoener 1971), assuming food sources of similar energy content.

An alternative to mouth feeding on the surface exists; worms might switch to subsurface-deposit feeding while not exposed. While we did not observe subsurface feeding by Rhynchospio glutaeus or Pseudopolydora kempi japonica without palps during the time that they were visible inside the tube, behaviors were difficult to identify and quantify if worms moved to depths below the field of view of the video camera. $P$. $k$. japonica with no palps spent significantly more time submerged (see Table 2B; time invisible), and it is possible they switched to subsurface feeding, but we did 
not see it. In addition, $P$. $k$. japonica with no palps often moved up and down in newly extended tubes, apparently licking the tube walls, though not ingesting sediment. If the worms were feeding, they would be doing so in the relative safety of the tube. Similar modifications of feeding behavior observed in tellinid bivalves have been presumed to be associated with attempts to avoid predation (Hughes 1969, Hughes 1973).

Fecal production provides a direct measurement of the food processed by the worms and, thus, an estimate of energy gain, as well as an evaluation of the effectiveness of switching to mouth feeding. Rates of fecal production should be equivalent to ingestion rate if the volume of ingested particles does not change during gut passage; this equivalence is especially likely when worms feed on deposited particles such as surface sediment (Taghon \& Greene 1992). The number of fecal rods produced in $2 \mathrm{~h}$ by Rhynchospio glutaeus remained the same regardless of palp loss, but Pseudopolydora kempi japonica with no palps defecated significantly less often than did controls or worms with 1 palp (Fig. 3). As measured by fecal production, P. k. japonica without palps did not compensate for palp loss by surface mouth feeding while $P . k$. japonica with 1 palp apparently compensated for palp loss even though they did not switch to surface mouth feeding (Figs. 2 \& 3). In contrast, $R$. glutaeus with 1 or no palps apparently compensated for palp loss by switching to mouth feeding (Fig. 2). An ANOVA showed no effect of palp number on the weight of feces produced by $R$. glutaeus with and without palps (MS $=0.104, F=1.3$, $\mathrm{df}=1,22, \mathrm{p}=0.2673$ ); fecal weight (dry weight) was determined by the following regressions using data gathered in previous, unpublished experiments: for intact worms, $\mathrm{mg}$ feces $=0.136 \times$ number of fecal rods $\pm 0.091, \mathrm{n}=40$, adjusted $\mathrm{r}^{2}=0.76$; for worms with no palps, $\mathrm{mg}$ feces $=0.167 \times$ number of rods $-0.004, \mathrm{n}=$ 40 , adjusted $r^{2}=0.79$. Because sediment grain size was similar in all cores, this suggests $R$. glutaeus with and without palps processed the same amount of sediment. Assuming similar organic content of the sediments ingested and no differences in assimilation efficiency, then energetic input would have been the same across all treatments.

Reduced fecal production by Pseudopolydora kempi japonica without palps clearly indicates that subsurface feeding, if it occurred, did not permit full compensation for the loss of both palps. However, P. k. japonica without palps produced $1 / 20$ th the volume of feces (Fig. 3) while spending 1/1000th of the absolute time feeding compared to intact worms (Table 2B). Therefore, greater than $50 \times$ more feces were produced than expected based on the time feeding. This is due either to increased collection efficiency by surface mouth feeding, or to unseen subsurface feeding. While mouth feeding, both Rhynchospio glutaeus and $P . k$. japonica often grabbed chunks of sediment, pulling them into the tube to ingest. Possibly, worms collected more sediment per unit time feeding with their mouths than with their palps. However, P. k. japonica without palps fed for such little time on the surface (Table 2, Figs. 1 \& $2)$, that even increased collection efficiency seems unlikely to account for the greater than expected fecal production. It seems more likely that $P . k$. japonica switched to subsurface feeding after losing both palps. although we can neither confirm that a switch occurred nor quantify how often it was employed in this study. In other laboratory experiments, P. $k$. japonica without palps clearly fed subsurface as indicated by the presence of marked sediment (from a layer approximately $0.5 \mathrm{~mm}$ below the surface) in their feces (Lindsay \& Woodin in press).

Most often, switches in diet and patch use, rather than foraging mode, have been described in response to such factors as environmental variability, food availability, competition, and predation risk, especially risk of lethal predation (Lima \& Dill 1990). For infauna, the risk associated with browsing predators is more complex. Certainly, infauna may regulate their activity to avoid browsing predation (e.g. tellinid bivalves feeding at night to avoid bottom feeding fishes, Levinton 1971), but once browsed, infauna may respond differently depending upon the type of tissue lost, the availability of alternative behaviors, and the risk associated with those behaviors. Considering the possible outcomes of an encounter between predator and prey described by Lima \& Dill (1990), where only a proportion of encounters culminate in prey capture followed by either death or escape of the prey, browsing of infauna might be classified as a type of encounter that always leads to prey escape, but which then may influence use of alternative feeding modes.

For infauna that lose feeding appendages, which, if any, alternative feeding mode is then employed may depend on morphological constraints as well as the relative risk to further predation associated with it. In this study, there were 2 alternative feeding modes available after feeding palp loss: surface mouth feeding and subsurface mouth feeding. Neither species was morphologically constrained from mouth feeding. In the field, surface mouth feeding may be accompanied by greater risk to predation since worms expose more body segments when feeding on the surface (Lindsay \& Woodin 1992).

Patterns of cryptic coloration suggest the difference between the species' responses to palp loss is related to predation risk. Rhynchospio glutaeus have about $3 \times$ as many translucent anterior body segments as Pseudopolydora kempi japonica (Woodin 1982), and the length of this translucent portion is also about $3 \times$ 
greater in $R$. glutaeus than in $P . k$. japonica (Woodin 1982, Lindsay \& Woodin 1992); thus, R. glutaeus may be less detectable on the surface by visual predators. This may be one reason why $R$. glutaeus switched to surface mouth feeding and apparently compensated for palp loss, while P. k. japonica did not (Fig. 2). Behavioral changes by $P . k$. japonica following palp loss were not without risk, however; worms tended to increase searching behavior on the surface (Fig. 1B), at the same time increasing body segment exposure. Given that food quality and quantity may vary on a scale of $1 \mathrm{~cm}^{2}$ or less (e.g. benthic microalgal distribution: Decho \& Fleeger 1988, Pinckney 1992), increased searching by $P$. $k$. japonica with no palps may represent an attempt to locate the most organically rich particles. This searching behavior should be more effective in the field than in our laboratory setting.

In fact, the relative selectivity of feeding may change with feeding mode. Depending on the habitat, suspension feeding can favor collection of smaller, of ten more organically rich, particles, and one might expect differences in particle selection between palp and mouth surface feeding, with palps collecting smaller particles. If we assume that the smallest particles are most energetically profitable, and that palp deposit feeding is biased towards collection of smaller particles compared to mouth feeding, then it is possible the increased time spent mouth feeding by Rhynchospio glutaeus with no palps would not result in energetic compensation if lower quality particles were ingested. Note, however, that $R$. glutaeus spent more time searching compared to Pseudopolydora kempi japonica, and this may indicate these worms are more selective. Because our goal was to determine how palp loss influenced worms' allocation of time to various behaviors and to document the use of available alternative feeding modes, we did not assess changes in selectivity. Thus, our estimates of compensation based on time spent feeding and fecal production are just that, estimates. To determine the energetic and ultimate fitness consequences of switching among feeding modes following palp loss requires separate experiments which account for potential differences in particle selectivity and assimilation efficiency.

Behavior of infauna feeding at the interface of the sediment surface and the overlying water column is clearly complex. Together, numerous aspects of feeding such as particle selectivity, feeding mode, and timing of feeding may define a foraging strategy. Each of these may be influenced by environmental conditions (hydrodynamic regime, local changes in food quality), predation risk, competitors, or damage to feeding appendages. We have focused on the response of common infaunal interface feeders, spionid polychaetes, to feeding appendage loss, documenting both switches to alternative feeding modes and alterations in the time allocated to feeding in the first few days following feeding palp loss. Clearly, use of alternative feeding behaviors will be governed by the same factors influencing normal feeding behaviors; our intent was to demonstrate that spionids losing feeding palps could use available alternative feeding modes. Additionally, because feeding palps are regenerated and the worms return to normal activity over time (after 8 to $10 \mathrm{~d}$, Pseudopolydora kempi japonica which lost 2 palps had regenerated palps roughly half the length of control palps, and fed in the same manner as intact worms; Rhynchospio glutaeus regenerated palps slightly more quickly), the potential advantage to the observed behavioral shifts will be determined in part by the frequency and timing of feeding palp loss in the field. Differences in habitat-specific predation pressure may help explain the differences between the feeding strategies of $R$. glutaeus and P. k. japonica. R. glutaeus occur lower in the intertidal and presumably have more time in a given tidal cycle to feed (and search) and during which they are exposed to predators. While roughly twice as many $R$. glutaeus collected from False Bay in 1989 and 1990 were missing 1 palp compared to $P$. $k$. japonica ( 17 vs $8 \%$ ), the percentage of individuals with no palps was the same for both species, $10 \%$ (Lindsay \& Woodin 1992).

The changes in behavior of the spionid polychaetes we observed suggest that dynamic foraging models similar to those of Houston et al. (1988), Mangel \& Clark (1988), and Burrows \& Hughes (1991) should investigate the possibility that animals switch between foraging modes as well as between diets and habitats. For some animals, such switches may be reflected in handling times rather than clearly defined switches in foraging mode such as we observed. Since these types of models incorporate fitness consequences of foraging decisions and are state dependent, costs of tissue loss may also be included (e.g. social and reproductive costs of tail loss in lizards; Fox \& Rostker 1982, Vitt \& Cooper 1986). Dynamic modelling of foraging by marine infauna is still in its infancy, yet several observations suggest these animals may be ideal subjects for investigating and modelling the importance of switching among feeding modes, as well as the role of injury (i.e. tissue loss) in influencing foraging behavior. First, switching among feeding modes in response to microhabitat and hydrodynamic conditions is common in a variety of infaunal taxa, especially interface feeders like the spionids studied here (Levinton 1991, Miller et al. 1992). Second, tissue loss to browsing predators is common; some losses involve feeding appendages, others do not. Different types of injury are very likely to cause different behavioral responses. In addition, responses to a similar injury (i.e. feeding appendage 
loss) may be very different between even closely related taxa, as we have shown. Clearly these organisms display complex switching behaviors which are driven by hydrodynamic factors, predators, tissue loss and risk. By exploring and modelling this interface, we can better predict the influence of injury on foraging decisions and the importance and success of switches among foraging behaviors.

Acknowledgements. Comments by James Eckman, David Lincoln, Stephen Stancyk, and David Wethey improved earlier versions of the manuscript. We appreciate the insightful comments of 3 anonymous reviewers. Dr A. O. D. Willows, Director of the Friday Harbor Marine Laboratories, University of Washington, kindly made the facilities of the laboratories and the protected habitats available. Dana Dunkelberger guided our exploration of Rhynchospio palps on the scanning electron microscope. S.M.L. thanks Paul Rawson, David and Suzanne Lindsay, and Courtney Richmond for their conversation, encouragement, and general moral support. Financial support was provided by an NSF Graduate Fellowship to S.M.L. and by NSF grant OCE-8900212 to S.A.W.

\section{LITERATURE CITED}

Blundon JA, Kennedy VS (1982) Refuges for infaunal bivalves from blue crab, Callinectes sapidus (Rathbun), predation in Chesapeake Bay. J exp mar Biol Ecol 65:67-81

Bowmer T, Keegan BF (1983) Field survey of the occurrence and significance of regeneration in Amphiura fillformis (Echinodermata: Ophiuroidea) from Galway Bay, west coast of Ireland. Mar Biol 74:65-71

Burrows MT, Hughes RN (1991) Optimal foraging decisions by dogwhelks, Nucella lapillus (L.): influences of mortality risk and rate-constrained digestion. Funct Ecol 5 : $461-475$

Caraco T, Wolf LL (1975) Ecological determinants of group sizes of foraging lions. Am Nat 109:343-352

Charnov EL (1976a) Optimal foraging: attack strategy of a mantid. Am Nat 110:141-151

Charnov EL (1976b) Optimal foraging, the marginal value theorem. Theor Populat Biol 9:129-136

Clavier J (1984) Production due to regeneration by Euclymene oerstedi (Claparède) (Polychaeta: Maldanidae) in the marine basin of the Rance (Northern Brittany). J exp mar Biol Ecol 75:97-106

Clements LAJ (1985) Post-autotomy feeding behavior of Micropholis gracillima (Stimpson): implications for regeneration. In: Keegon BF, O'Connor BDS (eds) Proc 5th International Echinoderm Conference, Galway, Ireland. AA Balkema, Rotterdam, p 609-615

Coen LD, Heck KL Jr (1991) The interacting effects of siphon nipping and habitat on bivalve (Mercenaria mercenaria (L.)) growth in a subtropical seagrass (Halodule wrighti Aschers.) meadow. J exp mar Biol Ecol 145:1-13

Daro MN, Polk P (1973) The autecology of Polydora ciliata along the Belgian coast. Neth J Sea Res 6:130-140

Dauer DM (1983) Functional morphology and feeding behavior of Scolelepis squamata (Polychaeta: Spionidae). Mar Biol 77:279-285

Dauer DM (1984) Functional morphology and feeding behavior of Streblospio benedicti (Polychaeta: Spionidae). In:
Hutchings PA (ed) Proc First International Polychaete Conference, Sydney. Linnean Society of New South Wales, Sydney, p 418-429

Dauer DM (1985) Functional morphology and feeding behavior of Paraprionospio pinnata (Polychaeta: Spionidae). Mar Biol 85:143-151

Dauer DM, Ewing RM (1991) Functional morphology and feeding behavior of Malococerus indicus (Polychaeta: Spionidae). Bull mar Sci 48:395-400

Dauer DM, Maybury CA, Ewing RM (1981) Feeding behavior and general ecology of several spionids from the Chesapeake Bay. J exp mar Biol Ecol 54:21-38

Decho A, Fleeger J (1988) Microscale dispersion of meiobenthic copepods in response to food-resource patchiness. $\mathrm{J}$ exp mar Biol Ecol 118:229-243

de Vlas J (1979a) Annual food intake by plaice and flounder in a tidal flat area in the Dutch Wadden Sea, with special reference to consumption of regenerating parts of macrobenthic prey. Neth J Sea Res 13:117-153

de Vlas J (1979b) Secondary production by tail regeneration in a tidal flat polulation of lugworms (Arenicola marina) cropped by flatfish. Neth J Sea Res 13:362-393

de Vlas J (1985) Secondary production by siphon regeneration in a tidal flat population of Macoma balthica. Neth J Sea Res 19:147-164

Dill LM (1987) Animal decision making and its ecological consequences: the future of aquatic ecology and behaviour. Can J Zool 65:803-811

Edwards R, Steele JH (1968) The ecology of 0-group plaice and common dabs at Loch Ewe. I. Population and food. $\mathrm{J}$ exp mar Biol Ecol 2:215-238

Fox SF, Rostker MA (1982) Social cost of tail loss in Uta stansburiana. Science 218:692-693

Holling CS (1959) The components of predation as revealed by a study of small mammal predation of the European Pine Sawfly. Can Entomol 91:293-320

Houston A, Clark C, McNamara J, Mangel M (1988) Dynamic models in behavioural and evolutionary ecology. Nature 332:29-34

Huey RB, Pianka ER (1981) Ecological consequences of foraging mode. Ecology 62:991-999

Hughes RN (1969) A study of feeding in Scobicularia plana. $\mathrm{J}$ mar biol Ass UK 49:805-823

Hughes RN (1980) Optimal foraging theory in the marine context. Oceanogr mar Biol A Rev 18:423-481

Hughes TG (1973) Deposit feeding in Abra tenuis (Bivalvia: Tellinacea). J Zool, Lond 171:499-512

Kamermans P, Huitema HJ (1994) Shrimp (Crangon crangon L.) browsing upon siphon tips inhibits feeding and growth in the bivalve Macoma balthica L. J exp mar Biol Ecol 175 . $59-75$

Krebs JR (1978) Optimal foraging: decision rules for predators. In: Krebs JR, Davies NB (eds) Behavioural ecology: an evolutionary approach. Sinauer \& Associates, Inc, Sunderland, MA, p 23-63

Levinton JS (1971) Control of tellinacean (Mollusca: Bivalvia) feeding behavior by predation. Limnol Oceanogr 16: $660-662$

Levinton JS (1991) Variable feeding behavior in three species of Macoma (Bivalvia: Tellinacea) as a response to water flow and sediment transport. Mar Biol 110:375-383

Lima SL, Dill LM (1990) Behavioral decisions made under risk of predation: a review and prospectus. Can J Zool 68: $619-640$

Lindsay SM, Woodin SA (1992) The effect of palp loss on feeding behavior of two spionid polychaetes: changes in exposure. Biol Bull 183:440-44? 
Lindsay SM, Woodin SA (in press) Quantifying sediment disturbance by browsed spionid polychaetes: implications for competitive and adult-larval interactions. J exp mar Biol Ecol

MacArthur RH, Pianka ER (1966) On optimal use of a patchy environment. Am Nat 100:603-609

Mangel M, Clark CW (1988) Dynamic modeling in behavioral ecology. Princeton University Press, Princeton, NJ

Miller DC, Bock MJ, Turner EJ (1992) Deposit and suspension feeding in oscillatory flows and sediment fluxes. J mar Res 50:489-520

Miller DC, Jumars PA (1986) Pellet accumulation, sediment supply, and crowding as determinants of surface depositfeeding rate in Pseudopolydora kempi japonica Imajima \& Hartman (Polychaeta: Spionidae). J exp mar Biol Ecol 99: $1-17$

Miller DC, Sternberg RW (1988) Fields measurements of the fluid and sediment-dynamic environment of a benthic deposit feeder. J mar Res 46:771-796

Peterson CH, Quammen ML (1982) Siphon nipping: its importance to small fishes and its impact on growth of the bivalve Protothaca staminea (Conrad). J exp mar Biol Ecol 63:249-268

Pinckney JL. Jr (1992) Ecology of intertidal benthic microalgal communities in North Inlet estuary, South Carolina. PhD dissertation, University of South Carolina, Columbia

Price HJ (1988) Feeding mechanisms in marine and freshwater zooplankton. Bull mar Sci 43:327-343

Price HJ, Paffenhofer GA (1986) Capture of small cells by the copepod Eucalanus elongatus. Limnol Oceanogr 31. 189-194

Schoener TW (1971) Theory of feeding strategies. A Rev Ecol Syst 2:369-404

Sih A (1982) Optimal patch use: variation in selective pressure for efficient foraging. Am Nat 120:666-685

This article was presented by K. R. Tenore (Senior Editorial Advisor), Solomons, Maryland, USA
Sih A (1987) Predators and prey lifestyles: an evolutionary and ecological overview. In: Kerfoot WC, Sih A (eds) Predation: direct and indirect impacts on aquatic communities. University Press of New England, Hanover, NH, p 203-224

Sokal RR, Rohlf FJ (1981) Biometry, 2nd edn. WH Freeman \& Co, San Francisco

Stancyk SE, Golde HM, Pape-Lindstrom PA, Dobson WE (1994) Born to lose: I. Measures of tissue loss and regeneration by the brittlestar Microphiopholis gracillima (Stimpson) (Echinodermata: Ophiuroidea). Mar Biol 118: $451-462$

Stephens DW, Krebs JR (1986) Foraging theory. Princeton University Press, Princeton, NJ

Taghon GL, Greene RR (1992) Utilization of deposited and suspended particulate matter by benthic 'interface' feeders. Limnol Oceanogr 37:1370-1391

Taghon GL, Nowell ARM, Jumars PA (1980) Induction of suspension feeding in spionid polychaetes by high particle fluxes. Science 210:562-564

Turner EJ, Miller DC (1990) Behavior of a passive suspensionfeeder Spiochaetopterus oculatus (Webster) under oscillatory flow. J exp mar Biol Ecol 149:123-137

Vitt LJ, Cooper WE Jr (1986) Tail loss, tail color, and predator escape in Eumeces (Lacertilia: Scincidae): age-specific differences in costs and benefits. Can J Zool 64:583-592

Woodin SA (1982) Browsing: important in marine sedimentary environments? Spionid polychaete examples. J exp mar Biol Ecol 60:35-45

Woodin SA (1984) Effects of browsing predators: activity changes in infauna following tissue loss. Biol Bull 116: $558-573$

Zajac RN (1985) The effects of sublethal predation on reproduction in the spionid polychaete Polydora ligni Webster. $\mathrm{J}$ exp mar Biol Ecol 88:1-19

Manuscript first recejved: October 24, 1994

Revised version accepted: March 27, 1995 